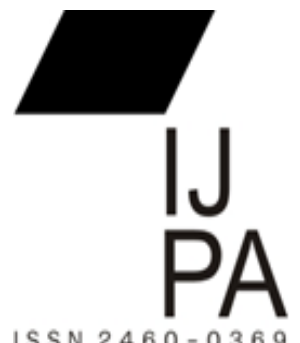

ISSN $2460-0369$

\title{
PENGEMBANGAN SUMBER DAYA MANUSIA DI DINAS PARAWISATA KABUPATEN KUPANG
}

\author{
Apriyani Ireny Osman \\ Frans. Gana \\ M.N.C.B. Neolaka

\section{Universitas Nusa Cendana Kupang irenyosman@gmail.com}

\begin{abstract}
The development of human resources in the tourism service has not been adequate due to various aspects of the drivers and obstacles. This study aims to identify the aspects of the drivers and inhibitors of human resource development in the Kupang District Tourism Office. Research using qualitative descriptive methods. With interview and documentation data collection techniques. Data collected uses analytical content to classify human resource development and the driving and inhibiting aspects of human resource development. The results of this study the Tourism Office is trying to improve human resources for employees and destinations in Kupang Regency tourism.
\end{abstract}

Key words: development, human resources, tourism

\begin{abstract}
Abstrak, Pengembangan sumber daya manusia di dinas pariwisata belum memadai karena berbagai aspek pendorong dan penghambat. Penelitian ini bertujuan untuk mengengtahui aspek-aspek pendorong dan penghambat pengembangan sumber daya manusia di Dinas Pariwisata Kabupaten Kupang. Penelitian menggunakan metode deskriptif kualitatif. Dengan teknik pengumpulan data wawancara dan dokumentasi. Data terkumpul menggunakan konten analisis untuk mengklasifikasi pengembangan sumber daya manusia dan aspek-aspek pendorong dan penghambat pengembangan sumber daya manusia. Hasil penelitian ini Dinas Pariwisata sedang berupaya untuk meningkatkan sumber daya manusia bagi para pegawai dan destinasidestinasi yang ada di pariwisata Kabupaten Kupang.
\end{abstract}

Kata kunci: pengembangan, sumber daya manusia, pariwisata 


\section{PENDAHULUAN}

Pariwisata sekarang ini telah menjadi kebutuhan bagi masyarakat di berbagai lapisan bukan hanya untuk kalangan tertentu saja, sehingga dalam penangananya harus dilakukan dengan serius dan melibatkan pihak-pihak yang terkait, selain itu untuk mencapai semua tujuan pengembangan pariwisata, harus diadakan promosi agar potensi dan daya tarik wisata dapat lebih dikenal dan mampu menggerakkan calon wisatawan untuk mengunjungi dan menikmati tempat wisata. Dalam hal ini industri pariwisata berlomba-lomba menciptakan produk pariwisata yang lebih bervariasi menyangkut pelestarian dari obyek itu sendiri sesuai dengan tujuan pembangunan pariwisata yaitu untuk mengenalkan keindahan alam, budaya dan adat istiadat yang beraneka ragam.

Dalam sektor pariwisata juga terdapat beberapa masalah yang kita temui misalkan masalah pengembangan sumber daya manusia. Karena untuk menarik wisatawan berkunjung ke suatu tempat wisata maka harus adanya sumber daya manusia yang memadai sehingga para wisatawan merasa puas dengan tempat wisata tersebut.

Misalkan Sumber daya manusia di Dinas Pariwisata di Kabupaten Kupang, sumber daya manusia menjadi kunci kelangsungan aktivitas kerja organisasi, karena organisasi itu sendiri pada hakekatnya adalah kerjasama antar manusia untuk mencapai tujuan tertentu. Oleh karena itu mekanisme dan sisitem yang ada dalam organisasi akan bermuara pada satu sumber, yaitu manusia.

Dinas pariwasata Kabupaten Kupang juga sudah melakukan beberapa kegiatankegiatan untuk menarik minat para wisatawan untuk dapat berkunjung dan menikmati tempat-tempat wisata yang berada di Kabupaten Kupang. Kegiatan - kegiatan yang telah dilaksanakan antara lain pengembangan pemasaran pariwisata, pengembangan kemitraan kepariwisataan, pengembangan destinasi pariwisata dan terakhir pengembangan ekonomi kreatif daerah

Namun demikian masih sangat jauh dari yang diharapkan, Dinas Pariwisata masih mengalami keterbatasan dalam memberikan pelayanan kepada masyarakat, yaitu masih kurangnya kualitas sumber daya manusia serta kualitas sarana prasarana pariwisata sehingga menyebabkan pengembangan sumber daya manusianya belum begitu baik.

Dari sisi dukungan anggaran untuk pariwisata di NTT masih sangat kurang. Tahun 2017 saja alokasi dana dari APBD hanya Rp 9 miliar untuk pariwisata, Kepala Dinas Pariwisata Provinsi Nusa Tenggara Timur Marianus Ardu Jelamu dalam "voxntt.com>berita terkini" mengatakan dukungan anggaran dari APBD untuk pengembangan sektor pariwisata di daerah ini masih sangat kurang, terutama untuk peningkatan promosi serta perbaikan infrastruktur pendukung.

Jadi minimnya pengembangan sumber daya manusia yang terjadi di dinas pariwisata Kabupaten Kupang bukan saja di karenakan oleh kurangnya jumlah dan 
karakteristik pegawai tetapi di sebabkan oleh kurangnya anggaran untuk bidang pariwisata.

Untuk meningkatkan pengembangan sumber daya manusia, dinas pariwisata kabupaten kuapang harus mempunyai visi dan misi untuk mencapai tujuan utama dari dinas pariwisata tersebut dan mendapat dukungan dari pemerintah Kabupaten Kupang. Masalah yang di hadapi adalah Pengembangan Sumber Daya Manusia Di Sektor Pariwisata Kabupaten Kupang.

\section{KAJIAN TEORITIS}

\section{Landasan Teori dan Pengembangan Hipotesis}

Pengembangan sumber daya manusia dapat dipahami sebagai penyiapan individu pegawai untuk memikul tanggung jawab yang berbeda atau lebih tinggi di dalam organisasi. Pengembangan biasanya berhubungan dengan peningkatan kemampuan intelektual atau emosional yang diperlukan untuk menunaikan pekerjaan yang lebih baik.

Pengembangan sumber daya manusia berpijak pada fakta bahwa individu pegawai membutuhkan pengetahuan, keahlian, dan kemampuan yang berkembang supaya ia mampu bekerja dengan baik. Pengembangan sumber daya manusia dapat mewujudkan melalui pengembangan karir, pendidikan, maupun penelatihan.

Menurut Sikula (2013;100), menyatakan bahwa pengembagan sumber daya manusia mengacu pada kepentingan staf dan personil yang ada di dalam organisasi. Pengembangan sumber daya manusia merupakan proses pembelajaran jangka panjang dengan menggunakan prosedur yang sistematis dan terorganisasi, dimana manajer mempelajari pengetahuan konseptual dan teoritis, yang kemudian diimplementasikan dalam pengembangan sumber daya manusia. Pengembangan sumber daya manusia juga merupakan aktivitas memelihara dan meningkatkan kompetensi sumber daya manusia guna mencapai efektivitas organisasi. Teori-teori manejemen sumber daya manusia adalah kinerja pegawai, kompensasi, ketiga, kompetensi, komitmen pegawai, kepemimpinan.

Pengertian tentang pariwisata dan wisatawan timbul di Perancis pada akhir abad ke-7. Tahun 971 Maurice Menerbitkan buku petunjuk “The True Quide For Foreigners Travelling in France to Appriciate its Beealities, Learn the language and take exercise". Dalam buku ini disebutkan ada dua perjalanan yaitu perjalanan besar dan kecil (Grand Tour dan Perit Tour). Pertengahan abad ke-9 jumlah orang yang berwisata masih terbatas karena butuh waktu lama dan biaya besar, keamanan kurang terjamin, dan sarananya masih sederhana. Tetapi sesudah Revolusi Industri keadaan itu berubah, tidak hanya golongan elit saja yang bisa berpariwisata tapi kelas menengah juga. Hal ini ditunjang juga oleh adanya kereta api. Pada abad ke-10 terutama setelah perang dunia II kemajuan teknik produksi dan teknik penerbangan menimbulkan peledakan pariwisata. 
Perkembangan terkahir dalam pariwisata adalah munculnya perjalanan paket (Package tour).

Objek dan daya tarik wisata merupakan salah satu unsur penting dalam dunia kepariwisataan. Dimana objek dan daya tarik wisata dapat menyukseskan program pemerintah dalam melestarikan adat dan budaya bangsa sebagai asset yang dapat dijual kepada wisatawan. Objek dan daya tarik wisata dapat berupa alam, budaya, tata hidup dan sebagainya yang memiliki daya tarik dan nilai jual untuk dikunjungi ataupun dinikmati oleh wisatawan. Dalam arti luas, apa saja yang mempunyai daya tarik wisata atau menarik wisatawan dapat disebut sebagai objek dan daya tarik wisata. Produk pariwisata meliputi keseluruhan pelayanan yang diperoleh, dirasakan, dimiliki dan dinikmati oleh wisatawan sejak ia meninggalkan rumah, tempat tinggal sampai ke daerah wisata yang dipilihnya hingga kembali ke tempat asalnya. Adapun yang dimaksud dengan produk industri wisata adalah keseluruhan pelayanan yang diperoleh oleh wisatawan.

Komponen-komponen yang termasuk ke dalam sarana dan prasarana adalah produk yang nyata (Tangible Product) dan Produk yang tidak nyata (Intangible Product). Jadi kesimpulannya pariwisata merupakan perencanaan menyeluruh dan terpadu yang didasarkan atas hasil penelitian dan evaluasi serta mencakup masalah sarana, prasarana, fasilitas, dan daya dukung lingkungan, keanekaan obyek wisata, ekonomi, sosial, kebudayaan, pendidikan dan sektor-sektor lainnya agar pengembangan sesuai dengan keinginan pasar dan pasar potensial dan untuk menentukan pengembangan yang tepat.

Bayu Radiantoro Ari Darmawan Fakultas Ilmu Administrasi Universitas Brawijaya Malang (2018) tentang Analisis Perkembangan Kemampuan Sumber Daya Manusia Pada Objek Wisata (Studi Pada Objek Wisata Kampung Coklat Kabupaten Blitar). Penelitian ini menggunakan jenis penelitian deskriptif dengan pendekatan kualitatif. Adapun fokus penelitian ini pada perkembangan dan peningkatan kemampuan SDM (Sumber Daya Manusia) di objek wisata Kampung Coklat.

Penelitian ini hasilnya menunjukan bahwa kondisi kemampuan karyawan Pada awal perekrutan ditemukan dalam bidang keterampilan atau Keahlian Sesuai penelitian yang dilakukan di Kampung Coklat ditemukan bahwa kondisi keterampilan atau keahlian yang dimiliki oleh karyawan Kampung Coklat tergolong sangat minim.

\section{METODE PENELITIAN}

Penelitian ini menggunakan Metode deskriptif kualitatif dengan teknik pengumpulan data, berupa (1) wawancara, yaitu berupa kegiatan mewawancarai beberapa narasumber dan informan secara runtut berdasarkan instrument penelitian; (2) observasi, yaitu berupa kegiatan menentukan obyek fisik data; (3) penyampaian daftar pertanyaan/instrumen, yaitu dengan cara langsung di lapangan kepada para narasumber dan informan guna mengetahui pengembangan sumber daya manusia Kabupaten 
Kupang dan aspek pendukung dan pengemhambat pengembangan sumber daya manusia, (4) perekaman, yaitu merekam data yang diperoleh di lapangan; dan (5) pencatatan, yaitu mencatat secara ringkas hasil rekaman menjadi bahan tertulis.

Data dalam penelitian ini didapat secara lisan dan tulisan. Data lisan yang berupa hasil wawancara bersama narasumber dan informan, sedangkan data tertulis berupa struktur organisasi,laporan anggaran dan buku profil.

\section{HASIL DAN PEMBAHASAN}

Pengembangan sumber daya manusia dipandang sangat strategis sebagai upaya menciptakan dan mempertahankan institusi berkinerja tinggi sehingga mampu memberdayakan dirinya sendiri dan mampu beradaptasi dengan perubahan lingkungan. Drucker dalam Dharma (2000:33) mengatakan bahwa, tiap menajer di dalam sebuah organisasi akan upaya memiliki kesempatan untuk mendorong pengembanagan diri karyawannnya ataupun menghalanginya, mengarahkannya atau tidak mengarahkanaya. Ia harus secara khusus diberi tanggung jawab untuk membantu semua orang yang bekerja dengannya untuk memfokuskan, mengarahkan dan melaksanakan upaya-upaya pengembangan diri mereka secara produktif.

Adapun upaya pengembangan SDM untuk meningkatkan aktivitas dan pengetahuan bagi pegawai dan masyarakat melalui bimtek dan pelatihan-pelatihan untuk pegawai di dinas pariwisata dan dari pelatihan-pelatihan tersebut adapun upaya peningkatan SDM di destinasi-destanasi agar dapat menarik banyak wisatawan.

Dalam perencanaan pengembanagn SDM dinas pariwisata saat ini sesuai dengan hasil rapat tahunan dinas pariwisata sedang mempersiapkan panitia untuk merekrut orang-orang (pegawai) sesuia dengan jenis pelatihan untuk di bentuk tim khusus.

Sehingga dapat diketahui bahwa dinas pariwisata untuk tahun ini sedang berupaya untuk meningkatkan SDM melalui pembentukan tim-tim khusus terutama dalam menggunakan IT untuk promosi-promsi tempat wisata yang ada di Kabupaten Kupang. Disimpulkan bahwa pengembangan sumber daya manusia di dinas pariwisata kabupaten kupang sementara di upayakan agar dapat meningkatakan kualitas sumber daya manusia kepariwisataan melalui model-model baru yang di kembangkan dengan menggunakan IT.

Dalam setiap instansi pemerintah pasti adanya upaya pengembangan sumber daya manusia di berbagai bidang dan dalam upaya pengembangan sering ditemui aspek pendukung dan penghambat, seperti pada Dinas Pariwisata Kabupaten Kupang yang sedang berupaya untuk meningkatkan kualitas sumber daya manusia kepariwisataan dan ternyata ada aspek-aspek pendukung dan penghambat dalam upaya pengembangan sumber daya manusia.

Adapun aspek-aspek pendukung dalam berbagai bidang adalah keterampilan dan pengalaman. Seperti halnya dinas pariwisata sangat membutuhkan pegawai-pegawai yang mempunyai keterampilan-keterampilan khusus oleh sebab itu dari dinas sering 
mengikut sertakan pegawainya dalam bimtek dan pelatihan-pelatihan untuk meningkatkan sumber daya manusia bagi para pegawai dinas pariwisata biasnya mengikut sertakan pegawainya setahun sekali dalam bimtek dan pelatihan-pelatihan agar nanti dapat di terapkan ke dinas sendiri dan juga kepada masyarakat.

Dalam meningkatkan sumber daya manusia dinas patiwisata tidak hanya mengikut sertakan pegawai dalam bimtek tersebut tetapi dari dinas juga mengikut sertakan masyarakat dalam bimtek tersebut untuk kegiatan atau even-even yang sering dilakukan oleh dinas pariwisata setiap tahunnya, even-evennya itu seperti motor cross,pacuan kuda,kontes sapi dan promosi kuliner karena untuk even-even ini membutuhkan orang-orang yang berketrampilan khusus sehingga dari dinas harus mengikut sertakan masyarakat dalam pelatihan-pelatihan atau bimtek.

Dapat diketahui bahwa untuk meningkatakan pengetahuan bagi para pegawai dinas pariwisata mengikut sertakan pegawai-pegawainya dalam pelatihan-pelatihan di luar daerah. Tetapi bukan hanya untuk pegawai-pegawainya saja, masyarakat juga di sertakan karena untuk pengembangan destinasi-destinasi yang ada pada dinas pariwisata dan untuk event-event yang sering dilaksanakan oleh dinas pariwista membutuhkan orang-orang yang berketrampilan khusus dan bantuan dari masyarakat.

Jadi untuk meningkatkan pengembangan sumber daya manusia pada pegawai di Dinas Pariwisata dan masyarakat Kabupaten Kupang sangat di butuhkan orang-orang yang berketrampilan khusus agar dapat melaksanakan tugas pada bidang dengan baik dan itu dengan cara mengikut sertakan mereka pada kegiatan-kegiatan seperti bimtek dan pelatihan-pelatihan yang nantinya di terapkan pada destinasi-destinasi wisata yang ada pada pariwisata Kabupaten Kupang.

Suatu organisasi terkadang penempatan pegawai dilihat dari pengalaman dan lamanya bekerja untuk meningkatkan pegembangan sumber daya manusia, seperti yang terjadi pada dinas pariwisata Kabupaten Kupang.

Dinas pariwisata dalam menempatkan tenaga ahli dalam bidang pengembangan sumber daya manusia dilihat dari lamanya seseorang bekerja yang dianggap sudah berpengalaman. Adapula pernyataan dari Kepala Dinas Pariwisata mengenai penempatan tenga ahli yang dipilih sesuai dengan pengalaman atau lamanya bekerja di harapkan kedepannya tidak lagi seperti itu tetapi harus dilihat dari latar belakang pendidikannya.

Disimpulkan bahwa dari dinas pariwisata sangat mengharapkan kedepannya dalam menentukan tenaga ahli dalam bidang pengembangan sumber daya manusia tidak dilahat dari pengalaman atau lamanya bekerja tapi dilihat dari latar belakang pendidikan dengan harapan dapat melayani masyarakat dengan baik.

Adapun aspek-aspek penghambat dalam berbagai bidang yakni pendidikan dan anggaran. Kita ketahui pendidikan menjadi penting bagi instansi-instansi pemerintah, karena pemerintah merekrut pegawai dengan melihat dari latar belakang pendidikannya. 
Agar dalam menjalakan tugas dan tanggung jawabnya mendapatkan hasil yang baik, tetapi dalam penempatanya pemerintah tidak menempatkan sesuai dengan besic atau latar belakang pendidikannya sehingga membuat pegawai-pegawai sedikit terlambat dalam menyelesaikan tugas dan tanggung jawab mereka karena mereka harus belajar lagi. Seperti yang ada pada dinas pariwisata Kabupaten Kupang untuk meningkatkan pengembanagn sumber daya manusia banyak pegawai yang harus diikut sertakan dalam pelatihan-pelatihan atau bimtek khusus pada bidang tersebut.

Pengembangan sumber daya manusia di dinas pariwisata kalau dilihat dari latar belakang pendidikannya masih sangat minim karena pengetahuan, pengalaman dan kemampuannya masih sangat rendah dan harus mengikuti pelatihan-pelatihan dan bimtek bagi pegawai-pegawainya agar dapat menjalankan tugas dan tanggung jawabnya dengan baik.

Diketahui bahwa penempatan pegawai di lakukan oleh BKD sehingga tidak sesuai dengan latar belakang oleh sebab itu untuk peningkatan pengembangan sumber daya manusia bagi para pegawai harus mengikuti pelatihan-pelatihan dan bimtek khusus.

Dinas pariwisata mengharapkan penempatan pegawai harus dilihat dari tinggkat pendidikannya sangat penting karena dilihat dari tinggkat indikator dan pemahaman seseorang saat di manfaatkan dan diberdayakan dia lebih mengekspor apa yang ada pada dirinya agar pelayanan bagi masyarakat dapat berjalan sesuai denganyang diharapkan, oleh sebab itu dinas sementara mengupayakan agar pegawai-pegawai dalam pengembangan sumber daya manusia mendapatkan studi banding sehingga dapat menjalankan tugas dan tanggung jawabnya dengan baik.

Hal yang dibutuhkan dalam memajukan kesejahteran suatu bangsa kita adalah banyaknya perubahan disegala lini dalam pengembangan-pengembangan yang ingin dilakukan, oleh sebab itu dalam pengembangan-pengembangan membutuhkan banyak anggaran karena kita tahu bahwa segala kebutuhan itu serba mahal. Misalkan dalam pengembangan-pengembangan pada instansi-instansi pemerintah harus membutuhkan banyak anggaran sebagai pendorong pengembangan-pengembangan tersebut untuk mendapatkan hasil yang baik.

Seperti yang penulis temui di dinas pariwisata Kabupaten Kupang pada pengembangan sumber daya manusianya masih sangat minim karena keterbatasan anggaran sehingga untuk meningkatkan pengembangan sumber daya manusia masih belum terlaksana dengan begitu baik. Untuk peningkatan pengembangan sumber daya manusia pada dinas pariwisata Kabupaten Kupang masih dibatasi dengan kerterbatasan dana yang ada sehingga dalam pengembangan sumber daya manusia masih sangat terbatas.

Para pegawai dan masyarakat yang mengikuti pelatihan dan bimtek masih sangat di batasi karena anggaran dari APBD masih sangat terbatas. Anggaran untuk 
pengembangan sumber daya manusia di dinas pariwisata masih sangat minim karena pengembangan SDM pada pegawai masih harus dikembangkan dan pengembangan SDM pada destinasi-destinasi masih harus ditata agar para wisatawan merasa puas ketika menikmati tempat-tempat wisata yang ada pada pariwisata Kabupaten Kupang.

\section{KESIMPULAN}

Berdasarkan hasil penelitian dan pembahasan secara umum dapat disimpulkan bahwa mengenai pengembangan sumber daya manusia di dinas pariwisata Kabupaten Kupang dalam upaya peningkatan pengembangan sumber daya manusia dalam berbagai bidang dan terutama pengembangan sumber daya manusia bagi pegawainya dan destinasi-destinasi yang ada di dinas pariwisata Kabupaten Kupang melalui pelatihanpelatihan dan bimbingan teknis tetapi semua itu masih dibatasi dengan anggaran.

Pengembanagn sumber daya manusia di dinas pariwisata sejauh ini sudah dijalankan dan ada aspek-aspek pendukung seperti pengalaman dan ketrampilan tetapi ada juga aspek penghamabat sehingga pengembangan sumber daya manusia di dinas pariwisata masih belum memadai karena masih banyak di batasi oleh tinggkat pendidikan dan ketersedian anggaran sehingga kedepannya diusahakan agar pengembangan sumber daya manusia di dinas pariwisata sudah lebih baik lagi dengan melihat dari latar belakang pendidikan dan dapat memberikan anggaran lebih besar lagi khususnya dalam pengembangan sumber daya manusia sesuai dengan misi dari dinas pariwisata Kabupaten Kupang yaitu meningkatkan kualitas sumber daya manusia kepariwisataan.

Saran yang dapat diberikan dalam penelitian ini adalah pertama, dinas pariwisata harus mempunyai tenagah professional sehingga kedepannya dalam pengembangan dunia wisata di Kabupaten Kupang memiliki daya kreatifitas yang tinggi. Kedua, diharapkan pemerintah daerah dalam merekrut pegawai dapat disesuaikan dengan latar belakang pendidikannya agar dapat memenuhi kebutuhan pada dinas pariwisata. Terakhir, pemerintah daerah maupun pusat harus lebih fokus pada anggaran untuk pengembangan sumber daya manusia pada pegawai dan destinasi-destinasi yang ada pada dinas pariwisata Kabupaten Kupang.

\section{DAFTAR PUSTAKA}

Cahayani Ati; 2005, Strategi dan Kebijakan Manajemen Sumber Daya Manusia, PT Indeks. Jakarta

Donni Juni Priansa, QWP, Mos,2014, Perencanaan dan Pengembangan Sumber Daya Manusia, Alfabeta, Bandung.

Fathoni Abdurahmat; 2009, Organisasi dan Manajemen Sumber Daya Manusia, Rineka Cipta, Jakarta

H. Oka A. Yoeti. MBA,2008,Perencanaan dan Pengembangan Pariwisata, PT Pradnya Paramita, Jakarta. 
H. Inu Kencana Syafile,M,Si.,2009,Pengantar Ilmu Pariwisata, CV. Mandar Maju, Bandung.

Hasibuan Malayu; 2009, Manajemen Sumber Daya Manusia, Bumi Aksara, Jakarta

Morpaung, Happy., 2002, Pengetahuan Kepariwisataan, Alfabeta.Bandung

Musanef,1 996, Manajemen Usaha Parawisata di Indonesia, PT.Toko Gunung Agung, Jakarta

Ross Glenn F.1998 Psikologi Parawisata,Yayasan Obor Indonesia, Jakarta

Salmun Jusupadi, 1989, Pengantar Parawisata sebagai Industri, PT.Dewi Sari Primula, Jakarta

Spillane J. James., 1987, Parawisata Indonesia Sejarah dan Prospeknya,Kanisius, Yogyakarta.

Sudarmayanti; 2008, Manajemen Sumber Daya Manusia (Reformasi Birokrasi dan ManajemenPegawai Negri Sipil,) Rafika Aditama, Bandung

Sudarmanto; 2009, Kinerja Dan Pengembangan Kompetensi Sumber Daya Manusia ( Teori, Dimensi Pengukuran, dan Implementasi Dalam Organisasi), Pustaka Pelajar, Yogyakarta

Suwanto H, dan Priansa Juni; 2013, Manajemen Sumber Daya Manusia Dalam Organisasi Publik dan Bisnis, Alfabeta, Bandung

Veitzal Rifai dan Eva Sagala; 2009, Manajemen Sumber Daya Manusia untuk Perusahaan: Dari Teori ke Praktik, Rajagrafindo Persada, Jakarta

Wiwoho B.Ratna Pudjawati dan Yulia Himawati,1990,Pariwisata Citra dan Manfaatnya,PT Bina Rena Pariwara,Jakarta

Yuniarsih dan Suwanto; 2009, Manajemen Sumber Daya Manusia ( Teori Aplikasi dan Isu Penelitian), Alfabeta Bandung.

\section{WEBSITE}

https://gamepos.id>Bahasa Indonesia. artikel Pengembangan sumber daya manusia https://pengertiandefenisi.com>pendidikan. Pengertian manejemen sumber daya manusi https://www.zonarefrensi.com>Refrensi .Pengembangan pariwisata

https://kakus.co,id>home.forum.bisnis.ekowisata sebagai alternative dalam pengembangan pariwisata

www.academia.edu/...Tesis_Analisis_Strategi_Pengembangan_Objek_Wisata_di_Malu ku_Tenggara 
Ilyas.Muhamad.2009.e.jurnals.unmul.ac.id/index.php.JAR.ARTICLE.VIEW.Strategi.Pe ngembangan.Pariwisata.Kepulauan.Togean.di.Kabupaten.Tojo.UnaUna.Penelitia n.ini.bertujuan.menyusun.strategi.dlam.mengembangka,kepariwisataan.Kepulau an.Togean

Luhpemi.Yudhiantari.2002.eprints.undip.ac.id/11719/.Ekowisata.sebagai.alterna tif.dalam.pengembangan.pariwisata.yang.berkelanjutan.di.Desa.Wongaya.Keca matan.Penebel.Kabupaten.Tabanan.Bali

Astawa.puja.2002etd.repository.ac.id.downloadfile/110045/.../S22017.Pola.Pengembangan.Pariwisata.Terpadu.Bertumpu.Pada.Model.Pemberday aan.Masyarakat.di.Wilayah.Bali.Tengah

B.Radiantoro.2018.administrasibisnis.studentjournal.ub.ac.id/indeks.php/jab.article,vie wfile.2357/.Analisis.Perkembangan.Kemampuan.Sumber.Daya.Manusia.Pada.O bjek.Wisata.Studi Pada .Objek Wisata Kampung Coklat Kabupaten Blitar 